DOI https://doi.org/10.30525/978-9934-26-184-8-5

\title{
ЗРОШЕННЯ В УКРАЇНІ $З$ ОГЛЯДУ НА СУЧАСНУ КЛІМАТИЧНУ СИТУАЦІЮ
}

\author{
Лиховид П. В. \\ кандидат сільськогосподарських наук, \\ докторант \\ Інститут зрошуваного землеробства \\ Національної академії аграрних наук України \\ смт Наддніпрянське, Херсонська область, Україна
}

Зрошення в умовах глобального потепління клімату набуває значення одного із головних факторів підвищення продуктивності аграрного сектору економіки. Особливо це стосується територій, які вже зараз належать до зони так званого ризикованого землеробства, де в річний період та впродовж вегетації більшості сільськогосподарських культур спостерігається істотний дефіцит природного водного балансу. Враховуючи стрімке підвищення температури повітря, яке за результатами аналітичного дослідження на території України проходить досить бурхливо, в основному за рахунок зимового періоду, очікуваним є наростання дефіциту природної вологи в державі. Так, прогноз розвитку температурної ситуації свідчить, що середньорічна температура повітря в Україні на майбутній період 2021-2050 рр. сягне позначки $+11,1 \ldots 11,2^{\circ} \mathrm{C}$. Комплексна оцінка розвитку ситуації 3 огляду на посушливість клімату за комбінованою методикою, що враховує такі показники як індекс аридності та природний режим вологи грунтів, свідчить про перехід практично всієї території України до напіваридної зони зі збільшенням площі орних земель, які потребують штучної подачі вологи для забезпечення стабільного надходження продукції рослинництва [1]. Прогнозування подальшої динаміки процесу свідчить, що найбільш істотні кліматичні зміни очікують такі регіони як Чернігівська, Харківська, Сумська, Вінницька області, але максимально посушливість клімату та погіршення ситуації в плані природного 
вологозабезпечення сільськогосподарських культур спостерігатиметься в Херсонській та Житомирській областях. Починаючи 32001 року червоною лінією простежується наростання потреб у зрошенні практично по всій території України. Наразі лише Львівська, Рівненська, Житомирська, Хмельницька, ІваноФранківська, Закарпатська, Волинська області не потребують або обмежено потребують зрошення для вирощування повного спектру сільськогосподарських культур з різними вимогами до вологозабезпечення, у той час як усі інші регіони держави потребують штучного зволоження.

На сьогоднішній день, лише близько 10\% потреб у зрошенні в Україні задоволені повною мірою. На тлі низької культури експлуатації зрошувальних мереж, їх моральної та технічної зношеності, відсутності достатнього фінансування та регуляторної політики з боку держави спостерігається катастрофічно низький рівень використання наявної зрошувальної потужності, не кажучи вже про розбудову нових мереж на територіях, які зараз потребують такого будівництва (Кіровоградська, Дніпропетровська, Харківська області, де фактична площа зрошуваних земель складає 198,7 тис. га, при тому що території цих регіонів у найближчому майбутньому з високою ймовірністю потерпатимуть від посухи на одному рівні з найбільш посушливою Херсонщиною) [2].

Таким чином, у найближчі десятиліття за відсутності прийняття відповідних заходів з розвитку зрошення в Україні та збереження кліматичного тренду, можемо очікувати на колапс галузі рослинництва через істотне зниження продуктивності незрошуваних орних земель.

\section{Лiтература:}

1. Lykhovyd P.V. Irrigation needs in Ukraine according to current aridity level. Journal of Ecological Engineering. 2021. Vol. 22(8). P. 11-18.

2. Юрченко Е. Зрошенню в Україні бути? Електронний pecypc. Режим доступу: http://agroportal.ua/ua/views/blogs/ orosheniyu-v-ukraine-byt/ (дата звернення 27.10.2021). 